\title{
How COVID-19 Pandemics Influences Chinese Economic Sustainability
}

\author{
Maksim Vasiev \\ PhD student, School of Economics and Management, vasievmp@yandex.ru
}

Kexin Bi ${ }^{*}$

Professor of Management Science and Engineering, School of Economics and Management, bikexin@hrbeu.edu.cn

Harbin Engineering University, Nangang district, Nantongdajie 149, 150001, Heilongjiang Province, Harbin, China

\begin{abstract}
Artem Denisov
Professor, Department of Computer Science, iptema@yandex.ru

Kostroma State University, 17, Dzerzhinskogo str., 156005, Kostroma, Russian Federation

\section{Vladimir Bocharnikov}

Professor, Wildlife Ecology and Conservation Laboratory, vbocharnikov@mail.ru

Pacific Geographical Institute, Far East Branch of the Russian Academy of Science, 7, Radio str., Vladivostok, 690041, Russian Federation
\end{abstract}

\begin{abstract}
C hina was the first country to face the COVID-19 coronavirus pandemic. Owing to the prompt and decisive actions of the authorities, and the consolidation of society, the country has passed the peak of infection and economic activity is gradually recovering.

The paper shows how COVID-19 affects key industries and the work of supply and transportation networks. Using input-output spatial data, migration index indicators, and pandemic spread statistics, we modeled different scenarios for changes in Chinese provinces' production and consumption following the COVID-19 pandemic. Calculations were made for 31 provinces and 42 sectors of the Chinese economy. We obtained a model that shows how the coronavirus outbreak influences carbon dioxide emission, levels of hazardous

waste, and the Energy-Resource Efficiency Rating. Based on the financial and migration flows between Chinese provinces, we chose the most effective post-outbreak model. Our main recommendation is that one does not need to segregate consumers. It is necessary to distribute the damage as evenly as possible between all provinces equally. We believe that such an approach will allow the Chinese economy to suffer the least possible amount of damage and facilitate a faster recovery. Finally, we analyze the development of bilateral post-epidemic financial flows between China and Russia until 2025. In all scenarios, a temporary decline is expected.

The results of the study may be useful for other countries in developing policies to overcome the postepidemic crisis.
\end{abstract}

Keywords: coronavirus (COVID-19); strategies; forecasting; sustainable development; post-coronavirus scenarios; SARIMA; input-output analysis; development programmes.
Citation: Vasiev M., Bi K., Denisov A., Bocharnikov V. (2020) How COVID-19 Pandemics Influences Chinese Economic Sustainability. Foresight and STI Governance, vol. 14, no 2, pp. 7-22. DOI: 10.17323/2500-2597.2020.2.7.22

\footnotetext{
${ }^{*}$ Correspondence author
} 
$\mathrm{T}$ he world is experiencing social and economic turmoil. Humanity is faced with environmental degradation, new viral outbreaks, and an uncontrollable decline in GDP [Ward et al., 2016]. Nowadays, it is essential not only to maximize profits, but to maintain economic stability and protect bio-diversity [Chou et al., 2018]. The most critical thing is to find a way to maintain balanced socioeconomic development and overcome postepidemic crises [Cao, 2019].

Since the widescale reforms in 1978, China has made remarkable progress in economic development [Yan et al., 2020]. After the financial crisis in 2008, the global economy entered a downward trend, but China's economic development maintained a medium-low growth rate. The high resilience of China's economic growth provides ample room for coping with external shocks in order to achieve high-quality development. The Chinese government put forward a sustainable development plan that considers not only quantitative growth, but also qualitative improvement in quality of life [Bei, 2018; Pan et al., 2019; Yan et al., 2020].

The COVID-19 coronavirus outbreak in Wuhan, China sparked a global epidemic at the end of 2019. As a result, on January 31, 2020 the World Health Organization declared an international emergency [WHO, 2020]. As with several crises, the repercussions of coronavirus can also be felt in the global economy and on financial markets. Many analysts compared coronavirus to the 2003 SARS outbreak. Even though this can offer useful information, there are radical differences between the two events. China controls a much larger part of the global economy and markets than it did 17 years ago. According to World Bank statistics, China's share of global trade increased to approximately $14 \%$ in 2019 compared to 5\% in 2003. Furthermore, its share of the MSCI Emerging Markets Index rose to almost 35\% in 2019 from $8 \%$ in 2003 [Bouoiyour, Selmi, 2020; Wen et al., 2020]. Thus, China's economy is taking a significant hit from the COVID-19 coronavirus outbreak [Allam, Jones, 2020].

Recent years have seen growing interest in studying prospects for economic development in post-epidemic periods. This interest has arisen along with the emergence of many new infectious diseases (over 30 in the past 25 years, including HIV/AIDS and severe acute respiratory syndrome (SARS)) as well as the return of old threats such as pandemic influenza [Wen et al., 2020]. In the same way, attention was turned to the new coronavirus in 2019. The exponential increase in the confirmed number of COVID-19 cases is of great concern for the global community [Wong et al., 2020]. The recent dynamics of the coronavirus outbreak allows one to suggest that this virus is more contagious than SARS was in 2003 [Lippi, Plebani, 2020]. Nowadays, the great challenge is for China to overcome the coronavirus outbreak. One of the opinions is that the influence of coronavirus on major projects such as China One Belt - One Road (OBOR) is limited and that delays will only impact them in the short term. Delays and the cessation of work on OBOR projects revealed, or rather, once again emphasized growing dependence upon China' new infrastructure. Even though the epidemic has declined in China itself, the governments of other countries such as the US, Italy, Spain, Germany, the UK, Iran, South Korea, and others are terrified of new outbreaks.

Even before the outbreak of the coronavirus epidemic, the Chinese government made severe adjustments to OBOR development plans. For example, it decided to slightly lower the tasks set for OBOR due to the severe slowdown in the development of the Chinese economy and an increasing wave of criticism in partner countries, who were dissatisfied with the conditions set by Beijing and, in particular, financial ones. However, China is convinced that the country would be able to fulfill the tasks set for the economy despite the pandemic and the OBOR project is the key task. China's inexhaustible resources and the stubbornness with which the Chinese people achieve their goals give reason to say that sometimes they can even do the impossible. China was the first to be impacted by the pandemic and now can use this opportunity to build the international community's confidence in it and show the world that it is a reliable partner capable of stabilizing the global situation.

In this paper, we compare situation in China's provinces and industries in order to identify which ones are most vulnerable. We perform a systematic analysis of the current position of and prospects for the Chinese economy, considering the estimated level of financial exchanges between China and Russia. Changes in production and consumption for each province of China are modeled. Historic input-output data serve as the information base as well as the latest statistics on migration and infection rates for COVID-19 coronavirus.

\section{Literature Review}

\section{The Pandemic's Impact upon the Global Economy}

China's economy is globally connected through trade, investment, and tourism, and any slowdown or persistent travel and transportation restrictions are likely to put pressure on global supply chains and potentially create worldwide economic fallout. Measures undertaken to hold the outbreak have significantly curtailed domestic and global transportation links, thus preventing the transportation of many products and decline of manufacturing inputs. 
Production has slowed across China, with sharp slowdowns in sectors concentrated in Hubei, such as auto parts, LCD panels, and pharmaceuticals. Manufacturing that recently shifted offshore to other parts of Asia still often depends upon intermediate inputs from China and thus is not insulated from China's production slowdown. At the firm level, companies in sectors such as hi-tech and automobiles or those that are exposed to China's tourism, retail, or other service sectors could take a significant hit. According to the United Nations World Tourism Organization, in 2018, China's outbound tourism sector spent $\$ 277$ billion, of which an estimated $\$ 36$ billion was in the United States ${ }^{1}$. US business will probably be affected by China's slowdown, including through shortages of inputs, the cancellation of some commercial activity, and potential increased costs related to an appreciating US dollar [CRS, 2020].

The major outbreaks can have a substantial economic impact upon the affected country, which is illustrated by the cases of SARS, MERS, and Ebola. According to some estimates, if the current epidemic is overcome within three months, it will likely lead a $0.8 \%$ drop in real GDP. In case of it lasting for nine months, the coronavirus outbreak will result in a $1.9 \%$ decline in GDP. GDP may fall more substantially if there are extended restrictions on movement and therefore upon trade and commerce [Smith et al., 2019]. Preliminary input-output data suggest that China's countermeasures and suppressed demand could limit the long-term economic impact of the COVID-19 outbreak [Duan et al., 2020]. In the short-term period, unfortunately, industrial production is expected to drop $18 \%$. China hosts more than 18 million small and medium enterprises that account for almost $80 \%$ of jobs and $50 \%$ of private firms' exports. These businesses have been severely affected by the coronavirus outbreak. Widespread disruptions in production, surging inventory costs from depressed domestic consumption, and rigid expenditures upon rents, wages, and interest altogether have impacted the fragile capital chain of SMEs, thus probably leading to numerous bankruptcies. The Chinese government has made swift and decisive efforts to control the spread of the virus. Depending upon the time taken for the outbreak to peak, measures able to mitigate short-term economic risks include campaigns for supporting small companies, policy incentives such as subsidies, delayed tax payments, reduced mortgage interest rates, and restoring market confidence through greater publicity and public scrutiny.

SARS is believed to be the first deadly infectious disease of the 21 st century. Starting in the Chinese province of Guangdong in November 2002, by
August 2003 it had spread to 29 countries and three regions, leading to 8,422 infections, of which there were 916 deaths. SARS was an unexpected negative shock in Hong Kong. The major adverse effects were on the demand side, with local consumption, tourism, and air travel services severely affected in the short term. The manufacturing base in the Pearl River Delta was unaffected, so the economy did not experience a supply shock, as the export of goods via Hong Kong continued. Initial alarmist estimates on the negative economic impacts were not borne out. After taking control of the outbreak, fear and panic quickly subsided and the economy rapidly rebounded [Siu, Wong, 2004].

The COVID-19 coronavirus outbreak has a much wider scale, thus illustrating the fact that infectious disease outbreaks can lead to severe economic disruptions [Brahmbhatt, Dutta, 2008]. Pandemics has already affected international trade as a whole. As World Trade Organization emphasized: "World trade is expected to fall by between $13 \%$ and $32 \%$ in 2020 as the COVID 19 pandemic disrupts normal economic activity and life around the world" [WTO, 2020].

\section{Ways to Find a New Sustainable Economy}

The Chinese government recognized the problems and undertook several steps, which resulted in some improvements. These reactions, however, were criticized as insufficient. In recent years, the Chinese public has realized the dangers of government environmental policies. The economic boom in China dramatically accelerated the destruction of country's resources since decisions were not made with rational and economic use of said resources in mind. The result was the severe depletion and imbalance of ecosystems, and as a result, an increase in pandemics.

The current environmental situation in China is not only the result of today's political choices, but also of the approaches, attitudes, and institutions that are brought forward over the centuries. Over the last few decades scientists have been trying to find a path towards a new sustainable economy. Emphasis has been placed upon the transition to a green economy by researchers such as Herman Daly [Daly, Farley, 2004; Daly, 2007], Cuttler J. Cleverland [Cleveland, 1999], Robert Costanza [Costanza et al., 2015], and others. Other researchers focus on quality of life and energy efficiency economy, such as Charles Hall in his work "EROI and Wealth of Nations" [Hall et al., 2014] and Jessica Lambert in the paper "Energy, EROI and quality of life" [Lambert et al., 2014]. In the new post-pandemic model of the economy, profit-making should not be the paramount task, but efforts

Available at: https://www.e-unwto.org/doi/pdf/10.18111/9789284421138, accessed 19.04.2020. 
to ensure balanced development should be emphasized. However, sustainability is a critical factor. ${ }^{2}$ Achieving the sustainable, gree development of human civilization is the most important and ambitious program of the international community aimed at ensuring a better future. Nevertheless, the implementation of this paradigm in all countries is far from perfect, despite the unprecedented efforts made over the past three decades [Bocharnikov, 2018a, 2018b].

It is now well-known that regions in Russian and China develop in a disproportionate manner. The level of economic development of regions and provinces is characterized by the gross regional product, the ratio of cash income to the subsistence level of the population, poverty level, and population density. Statistics for these indicators showed the areas for the most probable anthropogenic "penetration" of various forms of economic activity. The limits of the previous model of economic growth have been achieved, as a result, extraordinary public health challenges have arisen [Bocharnikov, 2012]. Thus, it is precisely in these areas of increased anthropogenic activity where various diseases and catastrophes suddenly arise. Scientists unanimously argue that the post-viral economy should be green, socially, ecologically, and environmentally oriented.

\section{Data}

Our research is based upon publicly available inter-provincial input-output tables which have been published by the China's National Bureau of Statistics every five years since 1992. We use the most recent officially published data for 2017 . Research has been done on the basis of China's thirty-one provinces. Russia input-output data for 2014 is from the WIND economic database ${ }^{3}$. Environmental, economic, and social data were used from the China Environmental Statistical Books and the EPS database ${ }^{4}$. Statistics on the spread of COVID-19 in China, including for Hubei province, for the period of January-March 2020, is presented the health section of the WeChat health platform. An inter-province migration index is contained on the Baidu Qianxi database ${ }^{5}$. Python code and calculation results as well as the data are available on the GitHub website ${ }^{6}$. A full list of data sources is represented in Table 1. China industries' abbreviation sheet is available in the Table 2. All data were cross-checked for consistency before processing, with the use of overlay tools and visual comparison.
Figure 1. Example of a Chinese Regional Input-Output Matrix

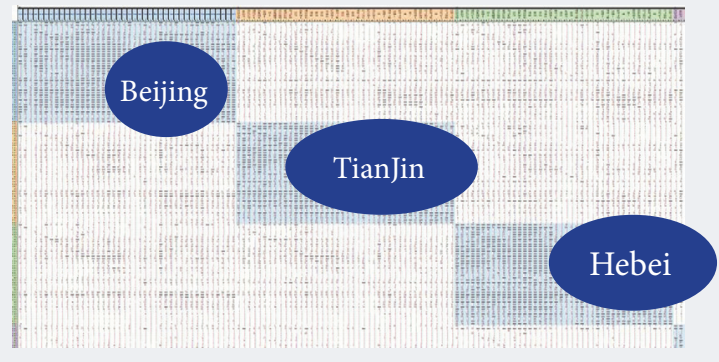

Source: [Yan et al., 2020].

\section{Methodology}

\section{Input-Output Efficiency Analysis}

Input and output analysis can systematically reveal not only the direct and obvious, but also the indirect, tacit links between various industries in the production process [Chen, 1990; Yan et al., 2020]. Input-output analysis provides a basis for studying the industrial structure and carrying out multiple quantitative analyses [Leontief, 2008]. The construction and usage of Input-Output Tables has been part of the analysis of China's economy since 1960. In 1973, Chen Xikang together with his colleagues constructed the first experimental inputoutput table for evaluating the national economy. Since then, the technologies of preparation, research, and application of input-output tables in China have rapidly improved [Yan et al., 2020].

The modeling of public Interprovincial InputOutput Tables [Oliveira, Antunes, 2011] and the Migration Index process is as follows:

Step 1: Calculate the closeness of links between the financial and migration flows for every province. Beijing, Tianjin, and other provinces (31 in total) are considered as separate subsystems, with their boundaries, and calculations made for every Subsystem-Province. Figure 1 shows an example of the China provinces' input-output table.

Step 2: Calculate input production efficiency and the potential reliable transportation channels, which are playing an essential role in the each provinces. For example, the authors ranked the transfers of products between provinces (thirtyone provinces multiplied by forty-two sectors' in-

\footnotetext{
Available at: https://www.wbcsd.org/COVID-19, accessed 13.04.2020.

3 Available at: https://www.wind.com.cn/en/edb.html, accessed 13.04.2020.

${ }^{4}$ Available at: http://olap.epsnet.com.cn/, accessed 13.04.2020.

Available at: http://qianxi.baidu.com/, accessed 13.04.2020)

${ }^{6}$ Available at: https://github.com/rufimich/Virus_prov, accessed 13.04.2020.
} 
Table 1. List of Research Indicators

\begin{tabular}{|c|c|c|c|}
\hline Area & Indicator & Code & Measure \\
\hline \multirow{7}{*}{ Social } & Population & $\mathrm{P}$ & bln \\
\hline & Unemployment rate & UR & $\%$ \\
\hline & Urban Land area, sq. km & LA & thousands of hectares \\
\hline & Highway density & HD & $\begin{array}{l}\text { The ratio of the total length of all roads of the } \\
\text { province to the province's area }(\mathrm{Km} \text { roads / } \\
100 \mathrm{~km} \wedge 2 \text { of the total area of the province } \\
(\mathrm{km} / 100 \mathrm{~km} \wedge 2))\end{array}$ \\
\hline & Passenger traffic & $\mathrm{PT}$ & $10000 \mathrm{p}$ \\
\hline & Average number of trips per person & ТPP & units \\
\hline & Number of employed persons & EP & 10000 \\
\hline \multirow{6}{*}{ Economic } & GDP & GDP & bln \\
\hline & GDP/person & $\mathrm{GDP}-\mathrm{P}$ & bln \\
\hline & $\begin{array}{l}\text { Total investments in environmental pollution } \\
\text { control }\end{array}$ & TIEPC & bln \\
\hline & Energy Efficiency Rating * & ENR & index \\
\hline & $\begin{array}{l}\text { Energy consumption }(10,000 \text { tons } \\
\text { of standard coal) }\end{array}$ & EC & ga/population \\
\hline & Technological Efficiency Rartiong * & $\mathrm{TE}$ & index \\
\hline \multirow{9}{*}{ Environmental } & Ratio of wilderness areas & RWA & $\%$ \\
\hline & Ratio of protected wilderness areas & RPWA & $\%$ \\
\hline & Ratio wilderness area/population & RWP & $\%$ \\
\hline & Total water consumption & TWC & hundred mln.cub.m \\
\hline & Consumption of gasoline & GC & hundred mln.cub.m \\
\hline & Hazardous waste ${ }^{\star}$ & HW & ten th tons \\
\hline & Waste water discharge & WW & thousand meters cub \\
\hline & $\mathrm{CO} 2$ emissions & $\mathrm{CO} 2$ & kg per kg of oil equivalent energy use \\
\hline & Eco-Efficiency Rating * & ERE & index \\
\hline \multicolumn{4}{|c|}{$\begin{array}{l}\text { Note: Indicators marked by }\left(^{*}\right) \text { are calculated using the ERA- Interfax methodology [Interfax, 2010]. Other indicators are taken from the EPS databa } \\
\text { (http://olap.epsnet.com.cn/). }\end{array}$} \\
\hline
\end{tabular}

put) from Hubei to other provinces. At the same time, the calculation results could show deliveries from Hubei (forty-two industrial sectors) to other provinces (thirty-one provinces * forty-two sectors input). Thus, on the basis of the input-output data, financial flows between Chinese provinces were modeled.

Step 3: On the basis of the migration index data, interprovince migration flows were modeled.

Step 4: On the basis of the Chinese and Russian input-output data, Sino-Russia financial flows after the coronavirus outbreak were forecast.

\section{SARIMA Analysis}

The authors used Python 3.4. modeling [Sarker, 2014; Scellato, 2013 $]^{7}$ to show how COVID-19 influences China's economic, social, and environmental factors. The authors tested twenty-three sustain- able factors. The testing methodology consists of the following steps: (1) the authors employed factor analysis; (2) the authors identified the most influential factors for Chinese provinces' sustainable indices; (3) the authors built the SARIMA (seasonal autoregressive integrated moving average) regression model.

\section{Scenario Modeling}

The authors calculated four different scenarios for the provinces' post-coronavirus economy by using the net-science methodology [Suarez et al., 2015]. In the end, the authors analyzed post-crisis financial flows between China and Russia. The scenario decision-making scheme is illustrated in Figure 2.

After determining the set of parameters for lowering the production level in Hubei province in accordance with each scenario, the reallocation of the 
Table 2. Abbreviation Sheet for Chinese Industries

\begin{tabular}{|c|c|}
\hline Industry & Code \\
\hline Agriculture & Agri \\
\hline Coal mining products & CoalM \\
\hline Oil and gas production products & OilgasM \\
\hline Metal mineral products & MetM \\
\hline $\begin{array}{l}\text { Non-metallic minerals and other mineral } \\
\text { products }\end{array}$ & NMetM \\
\hline Food and tobacco & Food \\
\hline Textile & Tex \\
\hline $\begin{array}{l}\text { Textile clothing shoes and hats leather down and } \\
\text { its products }\end{array}$ & Cloth \\
\hline Wood work and furniture & Wood \\
\hline Papermaking & Paper \\
\hline Petroleum & Fuel \\
\hline Chemical products & Chemi \\
\hline Non-metallic mineral products & NonMetP \\
\hline Metal smelting and calendering products & MetSm \\
\hline Metal products & MetInd \\
\hline General equipment & General \\
\hline Special equipment & Special \\
\hline Transportation equipment & TransEq \\
\hline Electrical machinery and equipment & Electri \\
\hline Communications equipment & ComEq \\
\hline Instrument and meter & Instr \\
\hline Other manufactured products & OtherM \\
\hline Scrap waste & Waste \\
\hline Metal products & EquiRepair \\
\hline Production and supply of electricity and heat & ElectriH \\
\hline Gas production and supply & GasPS \\
\hline Water production and supply & WaterPS \\
\hline Building & Building \\
\hline Wholesale and retail & WhSR \\
\hline Transportation & Trans \\
\hline Accommodation and catering & Accom \\
\hline Information transmission & Inform \\
\hline Financial & Fin \\
\hline The real estate & Estate \\
\hline Rental and business services & Rental \\
\hline Scientific research and technical services & Science \\
\hline Management of water conservancy & Cons \\
\hline Resident services & ResS \\
\hline Education & Edu \\
\hline Health and social work & Health \\
\hline Culture & Culture \\
\hline Public administration & PublA \\
\hline \multicolumn{2}{|l|}{ Source: authors. } \\
\hline
\end{tabular}

\section{Results}

\section{Regression Modeling Results}

The authors analyzed the input-output financial flows and the migration index between China provinces. In Table 3 and Figure 3 it is possible to see the mutual correlation between regional product from X-province and Y-migration index.

OLS regression results show that the minimum relationship between financial flows and the migration index is $1.099147 \mathrm{e}+06$ which is very close. It can be concluded that when migration flows are blocked in Hubei province, production will completely stop. Figure 3 clearly shows that when any virus spreads from a particular region, the regions that are closely connected to the source of the viruswill suffer the first.

The authors assumed that quarantine in the Hubei province would be six months. That situation would reduce annual production by half and reduce consumption by a quarter. How much would production in other regions be impacted?

The authors tested whether or not the financial flows between China provinces and industries would fall by $25 \%$. If supply of raw materials and parts from Hubei to other provinces ceases, production plans would be interrupted and this would impact all regions within the supply chain.

We can conclude that during the epidemic, economic activity is declining in all provinces. Mainly coronavirus spreads due to close economic ties and population flows. There is a very high correlation between them. If a source of the virus appears in a particular region, the regions that are economically connected to it will be the first to suffer. The authors evaluated the quality of the regression. If the government stimulates economic activity in all provinces proportionally, then in accordance with the principle of entropy, it will be possible to achieve the smallest reduction in China's GDP.

We used Python 3.4 to calculate the flows between provinces. Considering Beijing, Tianjinand, and other provinces (31 in total) as particular closed subsystems, we made calculations for every province. Our calculations revealed that that all the regions have an efficiency value near 1.5 and a potential value of about 5.8 , with minimal differences. Nevertheless, in terms of open systems, when considering the input and output from other provinces, the results are completely different. Figure 4 shows the financial flows between provinces. The most substantial flows are between Guangdong, Zhejiang, Jiangsu, Yunnan, Shanghai, Hebei, 
Figure 2. Decision Making Scheme for Scenario Modeling

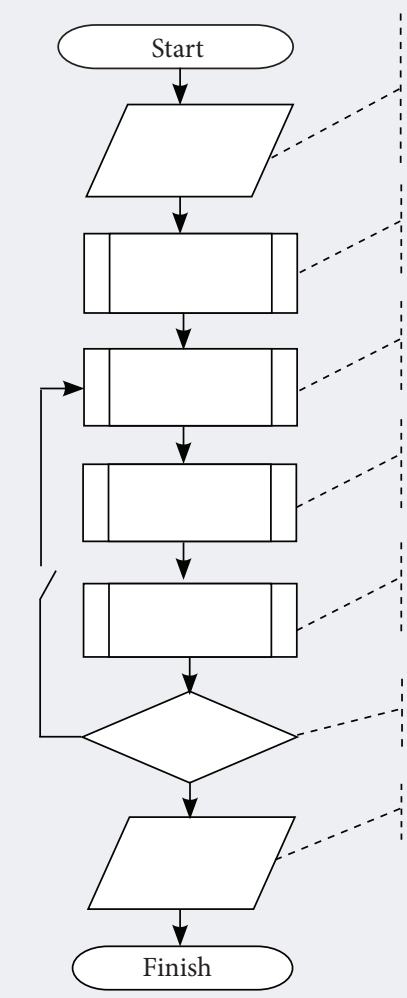

Source: Authors methodology.

Shandong, Beijing, Tianjin, and Inner Mongolia. Moreover, the flows illustrate the increasing links between China's central and western provinces such as those between Hubei and the Anhui and Jiangxi provinces.

Cross-regional entropy of the migration index closeness was measured amid the pandemic and in the post-crisis period. The higher the economic entropy of a region, the more stable the region is, the more interconnected it is, and the more susceptible it is to coronavirus. The effect of entropy also extends to migration flows. The most vulnerable areas are Jiangsu, Zhejiang, Guandong, and Shandong. The graph shows that financial flows are directly proportional to migration flows. As a result, regions with the highest migration indexes are the most susceptible to viral outbreaks.

\section{SARIMA Model Results}

The authors found dependencies between cases of infection and death from COVID-19 coronavirus and socioecologial and economic indicators for Chinese provinces (see Table 4). As a result, the authors obtained a model illustrating how the COVID-19 coronavirus outbreak influences carbon dioxide emissions, the level of hazardous waste, and the Energy-Resource Efficiency Rating (ERE) ${ }^{8}$. The model isas follows (see Table 1 for definitions of variables):

dfg1.columns=['P', 'UR', 'EP/P', 'UL/P', 'HD/GDP', 'PT/P', 'TR', 'WAR', 'HW', 'TWD',ESE', 'WA_P', 'GA', 'CO2_P', 'GDP', 'EC/P', 'ERE_GDP', 'TE/ GDP”TIEPC', 'PGR_GDP', 'Proc_D']

$\mathrm{m} 1=\operatorname{smf} .01 s$ ('Proc_D $\sim \mathrm{CO} 2 \_\mathrm{P}+\mathrm{HW}+\mathrm{ERE}_{-}$ GDP', data $=\operatorname{dfg} 1$ )

\section{Scenario Modeling for Chinese Provinces}

By analyzing cross-sectional data on the industries in the provinces and the sustainability of their transportation channels, the authors compiled four scenarios. Figures 5-10 show the modeling results of the drop in production in provinces in the case

\section{Figure 3. Interprovincial flows (million dollars) and the level of migration}

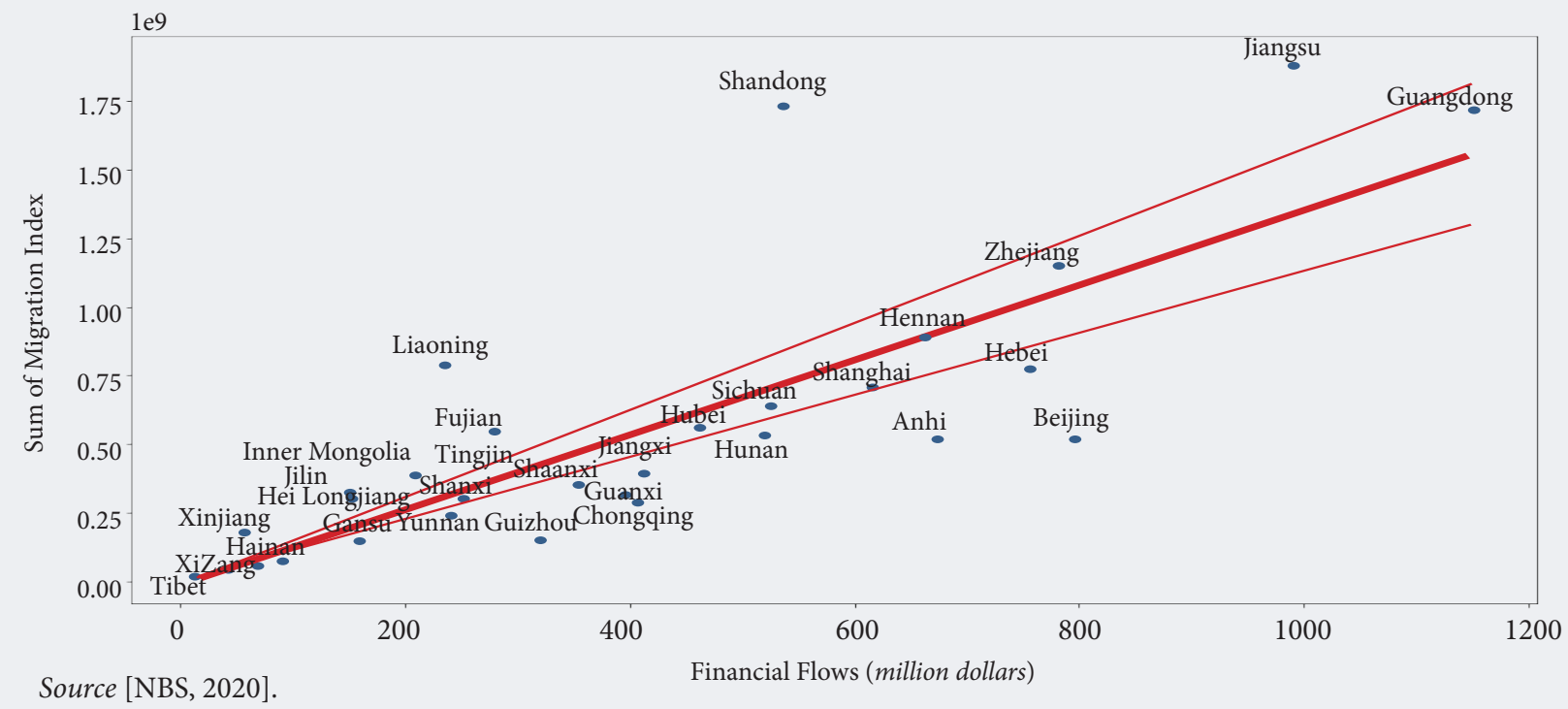

${ }^{8}$ The index was calculated by using the Interfax-ERA methodology [Interfax, 2010]. 
Table 3. OLS Regression Results

\begin{tabular}{|c|c|c|c|c|c|c|}
\hline \multicolumn{2}{|l|}{ Dep. Variable } & FinansialFlow & \multicolumn{3}{|l|}{$\mathrm{R}^{2}$} & 0.850 \\
\hline \multicolumn{2}{|l|}{ Model } & OLS & \multicolumn{3}{|c|}{ Adjusted $\mathrm{R}^{2}$} & 0.845 \\
\hline \multicolumn{2}{|l|}{ Method } & Least Squares & \multicolumn{3}{|c|}{ F-statistics } & 104.7 \\
\hline \multicolumn{2}{|l|}{ Date } & Sun, 12 Apr 2020 & \multicolumn{3}{|c|}{ Prob (F-statistics) } & $2.68 \mathrm{e}-11$ \\
\hline \multicolumn{2}{|l|}{ Time } & $06: 45: 49$ & \multicolumn{3}{|c|}{ Log-Likelihood } & -647.35 \\
\hline \multicolumn{2}{|l|}{ No. Observations } & 31 & \multicolumn{3}{|c|}{ AIC } & 1297. \\
\hline \multicolumn{2}{|l|}{ Df Residuals } & 30 & \multicolumn{3}{|c|}{ BIC } & 1298. \\
\hline \multicolumn{2}{|l|}{ Df Model } & 1 & \multicolumn{3}{|c|}{ Covariance Type } & $\mathrm{HC} 1$ \\
\hline \multicolumn{2}{|l|}{ Omnibus } & 18.892 & \multicolumn{3}{|c|}{ Durbin-Watson } & 2.013 \\
\hline \multicolumn{2}{|l|}{ Prob(Omnibus) } & 0.000 & \multicolumn{3}{|c|}{ Jarque-Bera (JB) } & 28.197 \\
\hline Skew & & 1.443 & Prol & & & $7.53 \mathrm{e}-07$ \\
\hline Kurtosis & & 6.674 & Con & & & 1.00 \\
\hline & coef & std err & $\mathrm{z}$ & $\mathrm{P}>|\mathrm{z}|$ & {$[0.025$} & $0.975]$ \\
\hline MigrationIndex & $1.36 \mathrm{e}+06$ & $1.33 \mathrm{e}+05$ & 10.231 & 0.000 & $1.1 \mathrm{e}+06$ & $1.62 \mathrm{e}+06$ \\
\hline
\end{tabular}

Note: in this and further tables and figures, unless indicated otherwise, the source is the authors' results obtained from the Python calculation: https:// github.com/rufimich/Virus_prov., accessed17.04.2020.

of a six-month shutdown in Hubei for both regions and industries.

Scenario 1. Economic activity in Hubei falls by $25 \%$ and product supplies to other regions are halted. The shortfall is distributed proportionally among all Chinese provinces that, due to a lack of resources, stop production and, as a result, stop supplying products to other regions. In this scenario, production in all provinces would drop $25 \%$.

Scenario 2. Products are delivered primarily under small contacts. Contracts for large amounts would be delayed for as long as possible (see Figures 5 and 6). In this case, the provinces and industries would suffer moderate damage. However, the poorly developed regions would most likely face a longer recovery period. The results of scenario modeling showed that not all unused resources in Hubei would be redistributed between other provinces.

If the extensive travel restrictions and quarantine policies continue, offline services including retail, catering, tourism, hospitality, transportation, and education and entertainment services would suffer the most [McCloskey, Heymann, 2020]. Government measures to cushion the shock such as loan payment deferments, social security contribution deferments, tax payment deferments, emergency credit facilities, and so on may be insuf-

\section{Figure 4. Financial Flows between Chinese Provinces}

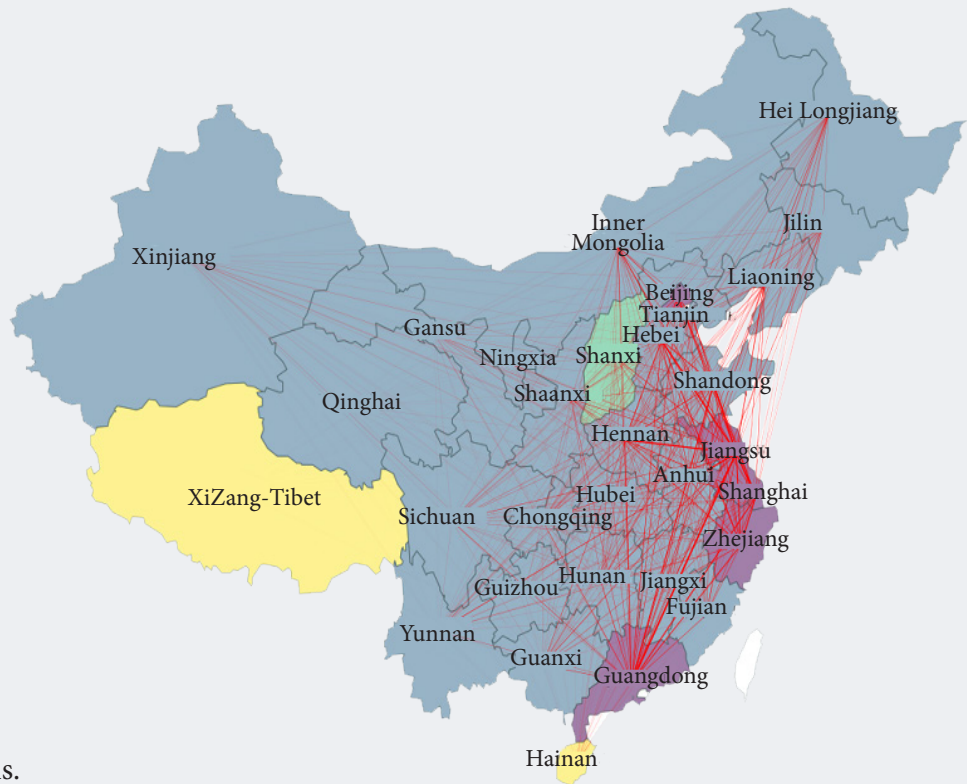


Table 4. OLS Regression Results

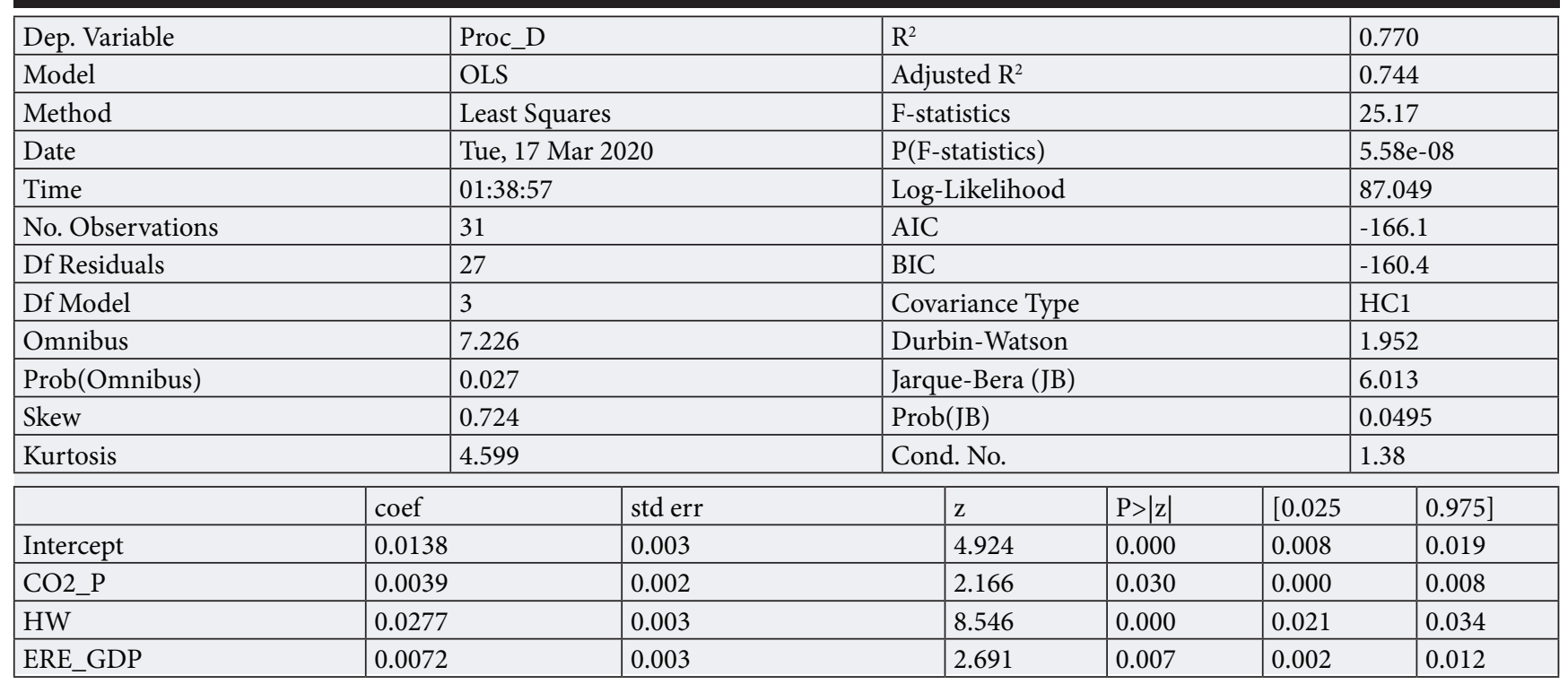

ficient to prevent the widespread bankruptcy of an enormous amount of Chinese SMEs, most of whom probably do not have many months of operating cash on hand. It is highly uncertain whether the aforementioned government measures will effectively contribute to the survival of such companies.

Well before the COVID-19 crisis, directives from central leadership for state banks to increase lending to SMEs largely fell flat. If the outbreak continues into Q2 2020 and significant travel restrictions remain in place, the cash flows for many SME services firms will inevitably be crushed. Defaults on loans and commercial payments will surge, as will layoffs. This will weigh heavily on consumption, which will in turn hurt goods manufacturers. If bankruptcies become widespread, the recovery will necessarily take much longer.
Scenario 3. This is similar to Scenario 2, however this scenario takes into account state support for the most affected provinces (see Figures 7 and 8). This is the worst case scenario. If this came to pass, all provinces would suffer, but the most poorly developed regions would be even more affected. Henan, Hubei, and Zhejiang would sustain the greatest losses because they are the leaders in terms of cumulative confirmed infections among all the provinces. All sectors would be damaged, more significantly than in other scenarios. At the same time the rating of each industry is similar to that in the first scenario.

Scenario 4. First, China provinces would give priority to contracts for orders from neighboring regions based on existing partnerships. The closer the customer is to the manufacturer, the more like-

\section{Figure 5. Effects of the Drop in Production by Region (Scenario II)}

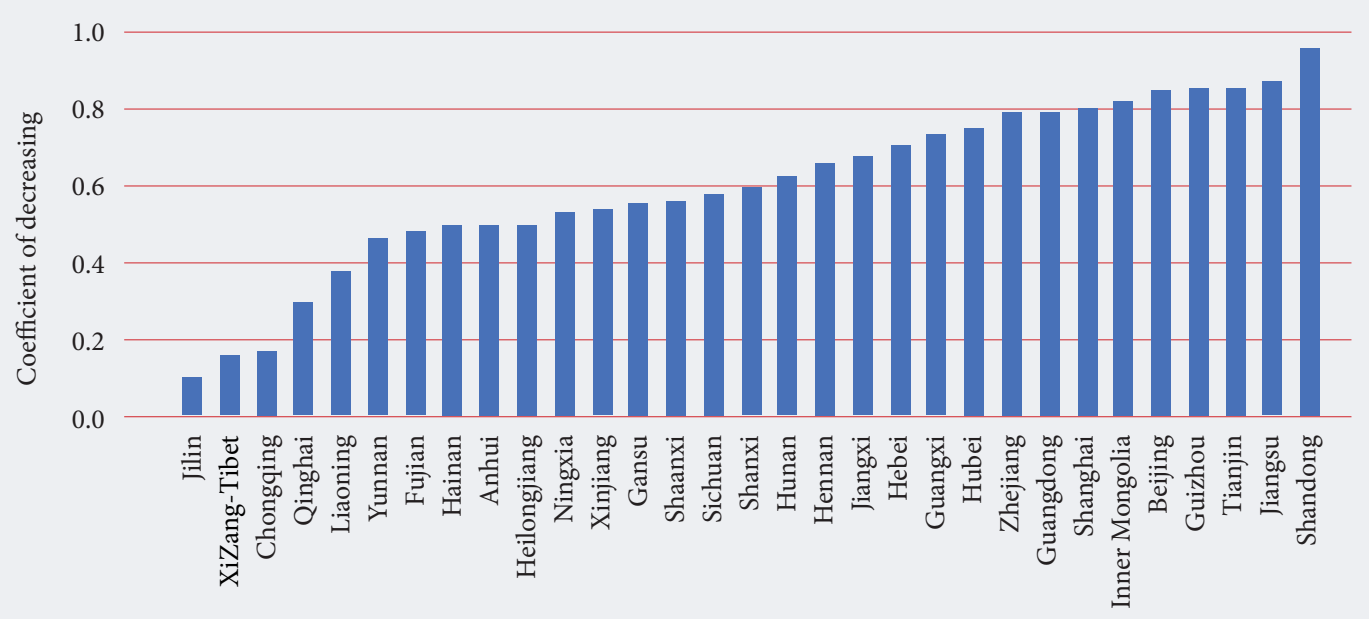

Source: authors' calculations. 


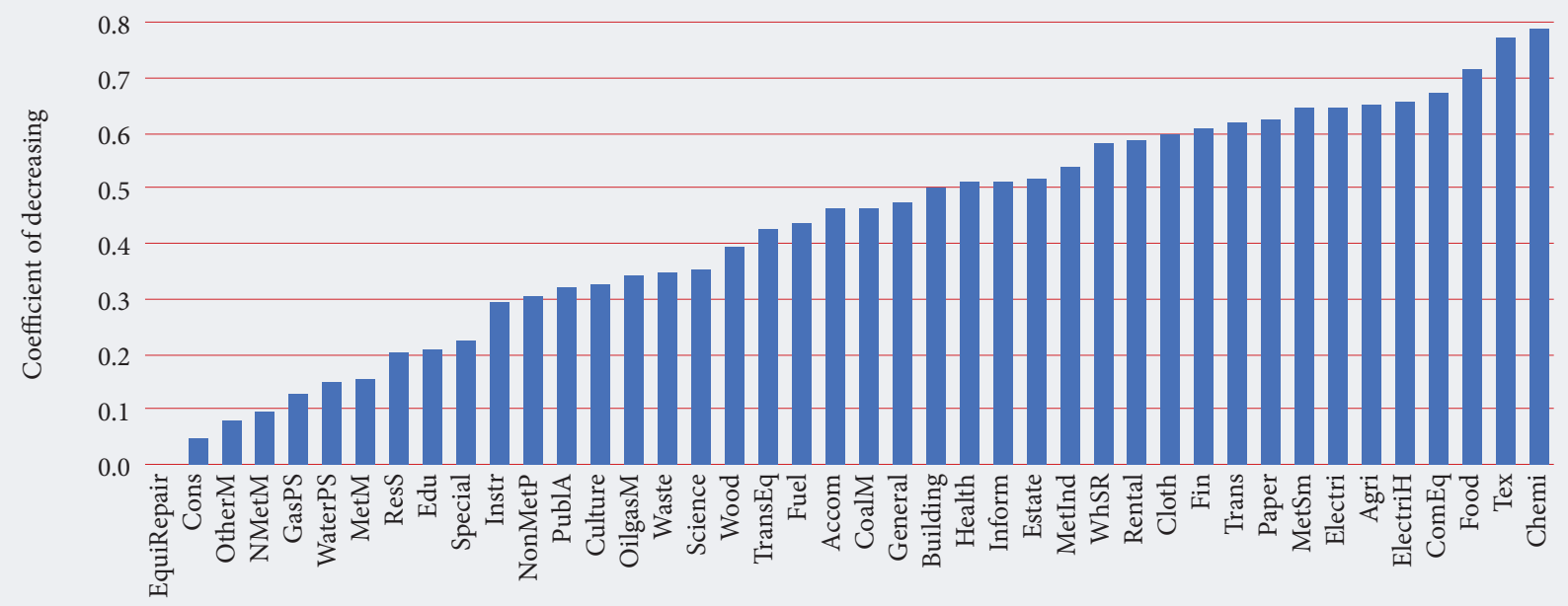

Note: for the definitions of industry abbreviations see Table 2.

Source: authors' calculations.

\section{Figure 7. Effects of the Drop in Production by Region (Scenario III)}

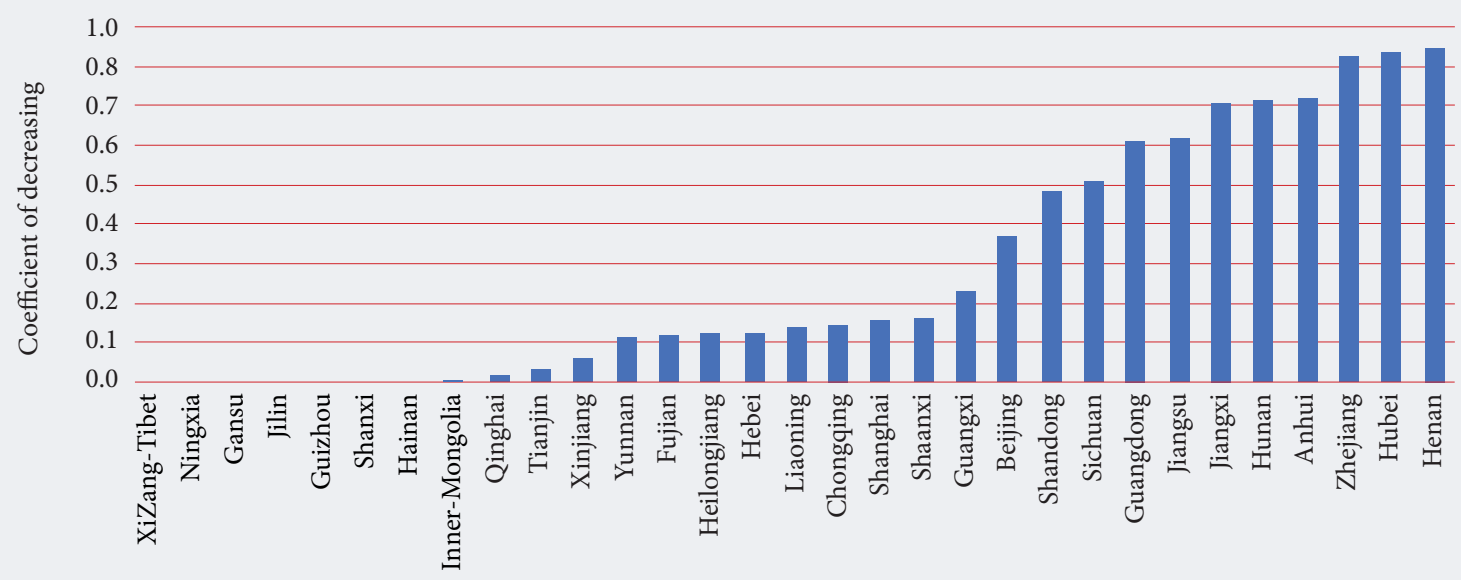

Source: authors' calculations.

Figure 8. Effects of the Drop in Production by Industry (Scenario III)

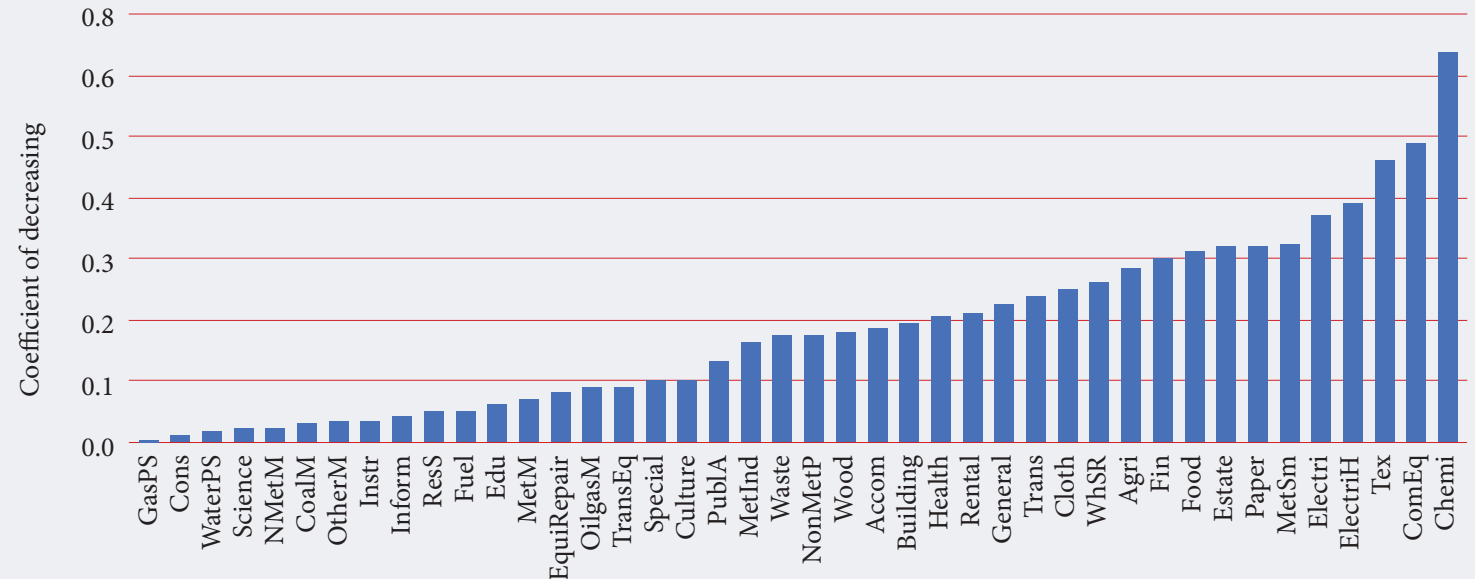

Note: for the definitions of industry abbreviations see Table 2.

Source: authors' calculations. 


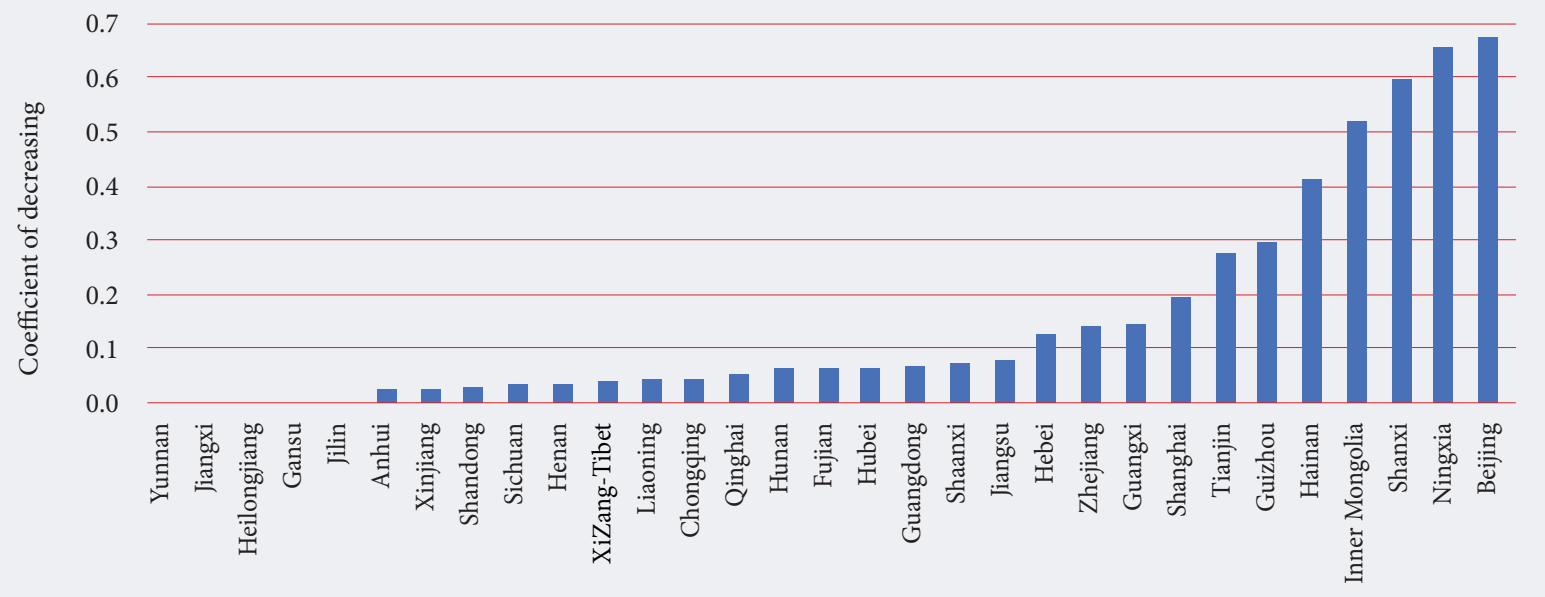

Source: authors' calculations.

ly it is that the obligations to the company would be fulfilled (see Figures 9 and 10).

In the last scenario, greatest amount of inequality is seen between the provinces. The higher the inequality, the more the province is more affected by the outbreak. A government decision to support only the strong sustainable provinces seems unethical. On the other hand, only allocating air to the weakest and most impacted provinces is also not enough. It is advisable to choose a damage mitigation policy on a consolidated basis. The even distribution of risks and losses between all regions seems to be the best scenario for overcoming the crisis.

The pandemic has made some mainstays of economic theory obsolete. The pressing needs "are to provide critical care and to break the chain of transmission of COVID-19, while keeping the population supplied and calm, for as long as it takes to get the job done" .

\section{Analysis of Financial Relations between China and Russia}

At present, the One Belt, One Road (OBOR) initiative is among the main priorities for China's foreign policy [Weidong, 2019]. At first glance, it distinguished by enough flexibility and openness for use on existing regional and multilateral platforms. Despite this, there has been little discussion about the compatibility of the OBOR objectives with existing Russian and Chinese foreign direct investments (further - FDI) projects [Ma et al., 2011; Liu et al., 2018]. In April 2019, the Second International Forum on OBOR took place in

\section{Figure 10. Effects of the Drop in Production by Industry (Scenario IV)}

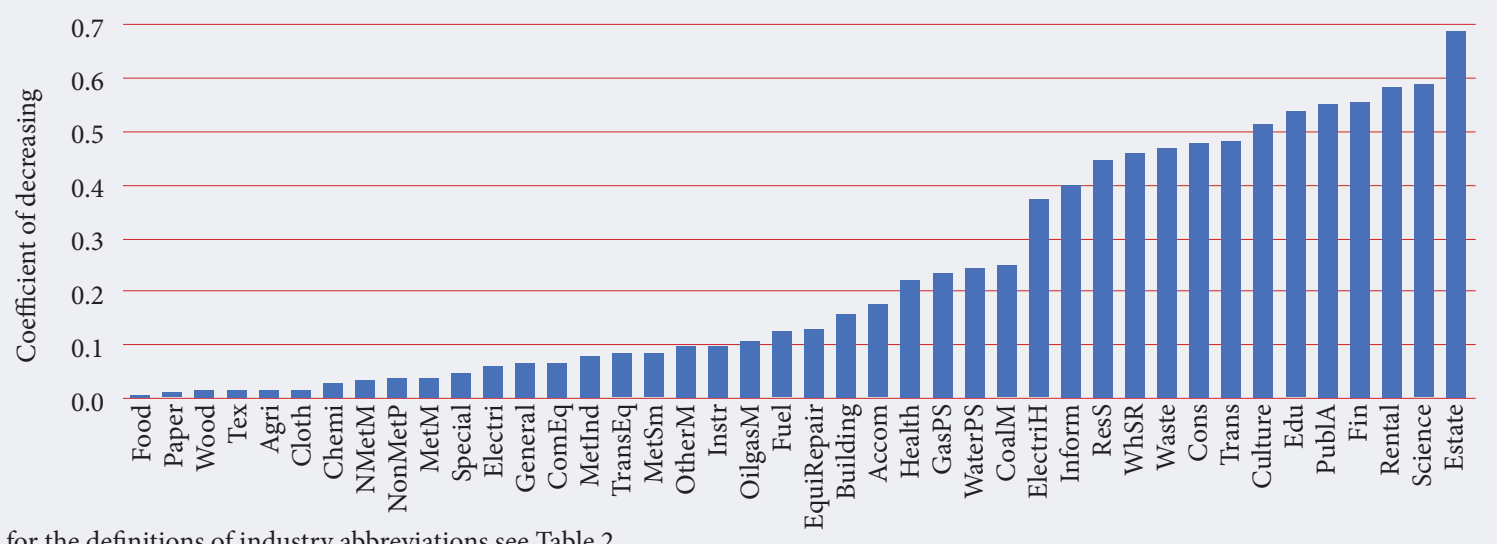

Note: for the definitions of industry abbreviations see Table 2.

Source: authors' calculations.

${ }^{9}$ Available at: https://lbj.utexas.edu/bad-economic-theory-and-practice-demolished, accessed 10.04.2020. 


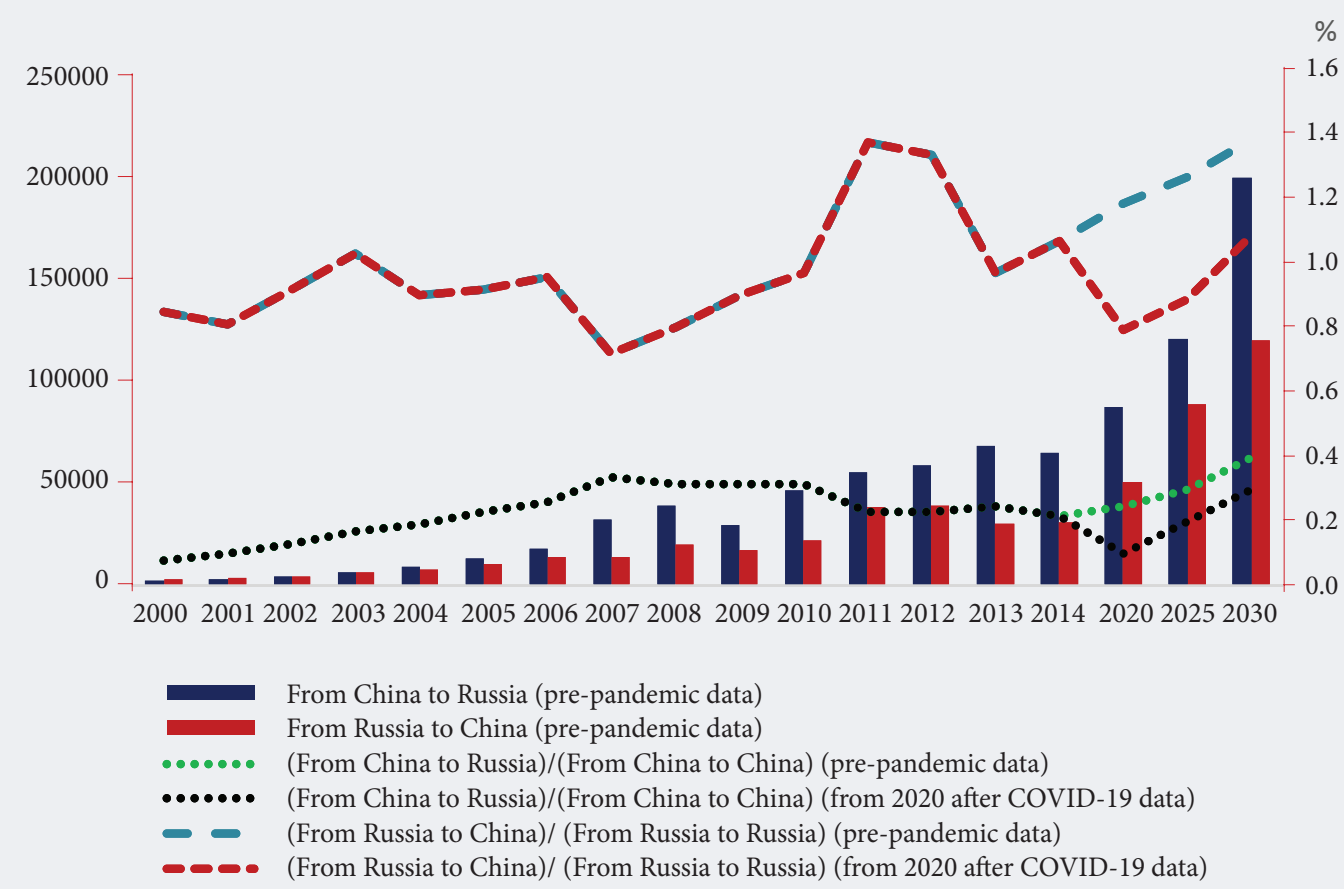

Sources: Historical dynamics are reflected in the statistical compilation "China Statistical Yearbook, 2019" [NBS, 2020]. The forecast has been compiled according to the CIC Advisor agency [CIC Advisor, 2020].

Beijing. About 40 leaders of the countries along the OBOR route and more than 1,000 experts and journalists participated. Chinese President Xi Jinping made the keynote speech at this forum. More than 140 cooperation agreements were signed there. The volume of Chinese investments in the projects of the countries along the route amounted to more than $\$ 80$ billion while the volume of tax and other kinds of payments exceeded $\$ 2$ billion. Russia is the one of the strategic partners in the OBOR project [Svetlicinii, 2018; Lanjian, Wei, 2016; Malle, 2017] Before the coronavirus outbreak, there were four prospective areas for Russian-Chinese trade and investment cooperation: energy resources, transportation, investments, and banking. It should be noted that development dynamics depend directly upon the intensity of trade [Steblyanskaya, Wang, 2019].

Figure 11 illustrates the bilateral Chinese-Russian financial flows from a historical point of view and a forecast until 2030. Financial flows from Russia to China were two to three times less intense than flows from China to Russia (Table 5). However, if we analyze the situation from another point of view, we can see that flows from China to Russia make up only $0.29 \%$ of Chinese turnover, which is a very small share. At the same time, the share of financial flows from Russia to China amounts to $1.08 \%$ of Russia's domestic turnover, respectively Chinese investments hold a higher share in the Russian economy. In absolute terms, China's activity in bilateral trade flows is notably higher than Russia's. Russia, despite its limited budget, tries to invest more funds to decrease this imbalance. Before the pandemic, Russia did not play a significant role in supporting China's trade balance. Is it possible that Russian-Chinese trade will grow in the future? Previous forecasts (before the COVID-19 outbreak) suggested that Russia would actively increase investments in Chinga, reaching an FDI share of $2.49 \%$ in comparison with China's $0.28 \%$ by 2030 . However, following the coronavirus outbreak, the authors expect financial flows between the two countries to decline until 2022-2025. Since the COVID-19 crisis is characterized by many unpredictable factors, it is impossible to forecast the situation with any reasonable degree of feasibility.

In connection with the decline in oil prices and COVID-19 coronavirus, a drop in demand for fuel and metals is expected. However, fuel and metallurgical industries provide the bulk of exports from Russia to China.

It must be emphasized that a wide range of options for the forecast decrease in trade turnover between the two countries can be explained by the unprecedented nature of the current health crisis and the uncertainty surrounding its precise economic impact. Estimates for the expected recovery in 2021 are equally uncertain, while the outcomes would 
Table 5. Forecasted Bilateral Financial Flows between Russia and China for the $\mathbf{1}^{\text {st }}$ Half of 2020

\begin{tabular}{|c|c|c|c|c|}
\hline \multirow{2}{*}{ Scenarios } & \multicolumn{2}{|c|}{$\begin{array}{c}\text { Imports from Russia } \\
\text { to China }\end{array}$} & \multicolumn{2}{c|}{$\begin{array}{c}\text { Exports from China } \\
\text { to Russia }\end{array}$} \\
\cline { 2 - 5 } & $\begin{array}{c}\text { Mln } \\
\text { USD }\end{array}$ & $\begin{array}{c}\text { \% of the pre- } \\
\text { crisis level }\end{array}$ & $\begin{array}{c}\text { Mln } \\
\text { USD }\end{array}$ & $\begin{array}{c}\text { \% of the pre- } \\
\text { crisis level }\end{array}$ \\
\hline 1 & 12884.5 & 75.0 & 22218.7 & 75.0 \\
\hline 2 & 8761.1 & 51.0 & 15554.0 & 52.5 \\
\hline 3 & 4281.1 & 24.9 & 3830.1 & 23.0 \\
\hline 4 & 3717.9 & 21.6 & 3830.1 & 12.9 \\
\hline
\end{tabular}

Note: According to the [CIC Advisor, 2020], the sum of imported products from Russia to China for the 1st half of 2020 was planned at the level of $\$ 18 \mathrm{bln}$; the total amount of exported products from China to Russia at the level of $\$ 29.625$.

Source: authors.

depend mainly upon the duration of the outbreak as well as the efficiency of policy responses.

\section{Conclusion}

China's economy has taken a significant hit from the COVID-19 coronavirus outbreak [Redding et al., 2019; Wen et al., 2020]. In this paper, the authors analyzed the post-coronavirus economy in China by employing systematic approaches using input-output data for 31 provinces and 42 industries and new data on COVID-19 for winter 20192020.

The authors used input-output analysis, SARIMA analysis, four scenario modeling, and modeling of the Chinese-Russian financial flows. First, the authors calculated the migration index and financial flows model to obtain insight into the migration flows between China provinces. Second, the authors obtained a model that showed how the infection and mortality rates of coronavirus influences carbon dioxide emissions, level of hazardous waste, and the Energy-Resource Efficiency Rating (ERE). Then, four scenarios were developed to show how a three-month halt in production in Hubei would impact industry behavior in other provinces. This approach was applied in order to identify economic imbalances in the provinces and prevent the worstcase scenario.

OLS regression results show that the minimum relationship between financial flows and the migration index is $1.099147 \mathrm{e}+06$, which is very close. It could be concluded that when migration flows are blocked in the Hubei province, production will completely stop Indeed, with the spread of any virus from a certain province, the first that will be impacted are those regions closely tied to the source of the virus. To define the impact of the COVID-19 infection and death rates upon Chinese regional development, 23 sustainable factors were tested. The obtained model attests to the pandemic's strong effect upon on carbon dioxide emissions, the level of hazardous waste, and the level of the Energy-Resource Efficiency Rating (ERE). We analyzed four scenarios for provinces' production and supply flows after the coronavirus outbreak.

Our main recommendation is that there is no need to segregate consumers. It is necessary to distribute the damage as evenly as possible. This will allow for minimizing the impact upon the Chinese economy and accelerating its recovery. If aid is provided to only certain provinces, the economic downturn will be more substantial as will harm from the drop in production (Scenarios 2-4).

Before the crisis, financial flows between China and Russia increased and growth was planned in the coming years. However, in the post-coronavirus period, it is difficult to make any forecasts about the level of trade. The situation may develop unpredictably. Besides, it is now a real challenge for the Chinese economy to stop importing cases of coronavirus from abroad, as there are more coronavirus cases and deaths in the US and Europe than in China. It is expected that due to the falling

\section{Figure 12. Structure of Imports from China to Russia, 2018 (millions of dollars)}

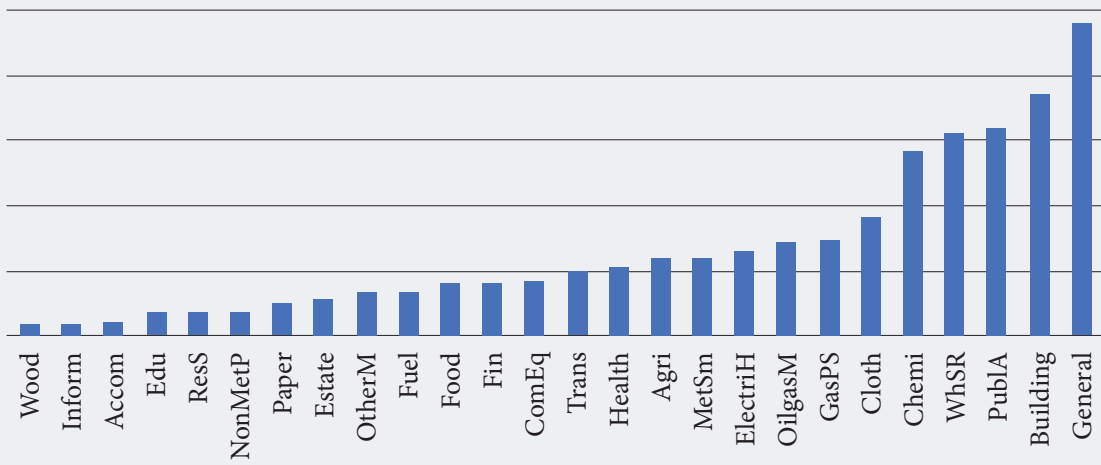

Note: for the definitions of industry abbreviations see Table 2.

Source: [NBS, 2020]. 


\section{Figure 13. Structure of Exports from Russia to China, 2018 (millions of dollars)}

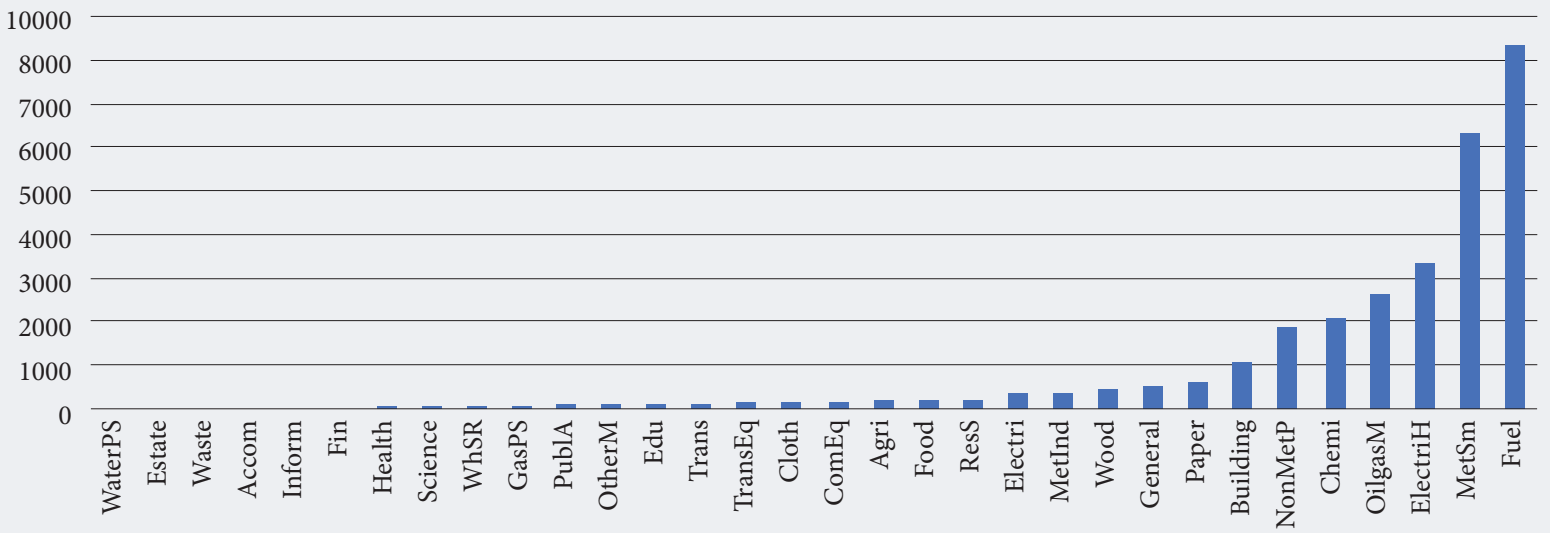

Note: for the definitions of industry abbreviations see Table 2 .

Source: [NBS, 2020].

prices of oil and other resources, China will buy up assets in the Russian Federation, which will affect the promotion of Chinese cultural and business standards. It is expected that relations between China and Russia will grow stronger in the future. Due to the growing interest in the transition to a green economy, digitalization technologies conducive to this initiative will developed as part of the OBOR project.

The impact of the post-coronavirus situation on the Chinese and global economy must be considered for further study. In order to thoroughly study macroeconomic trends for the development of
China and Russia, the consequences of emergency situations (epidemics, strikes, unemployment, etc.) must be evaluated. With this in mind, a neural network model could be created that provides a basis for decision-making and the formation of sustainable development strategies for responding to crises.

The research was accomplished with the support of the Fundamental Research Fund for the Central Universities within the projects "Sustainable Development of Green Silk Road from a Complex Network Perspective" (Project No. 3072020CFJ0901), and "Digitally Driven Green Intelligent Manufacturing and Energy Ecological Governance Research" (Project Number: 3072020CFW0903).

\section{References}

Allam Z., Jones D.S. (2020) On the Coronavirus (COVID-19) Outbreak and the Smart City Network: Universal Data Sharing Standards Coupled with Artificial Intelligence (AI) to Benefit Urban Health Monitoring and Management. Healthcare, vol. 8, no 1, art. 46. Available at: https://doi.org/10.3390/healthcare8010046, accessed 17.04.2020.

Bei J. (2018) Study on the "high-quality development" economics. China Political Economy, vol. 1, no 2, pp. 163-180. DOI 10.1108/CPE-10-2018-016.

Bocharnikov V. (2012) K geograficheskoi probleme sokhraneniya bioraznoobraziya i ekosistemnykh uslug rossiiskogo Dal'nego Vostoka [On the Issue of Geographic Problem of Biodiversity and Ecosystem Services Preservation in the Russian Far East]. Zashchita okruzhayushchei sredy v neftegazovom komplekse [Environmental Protection in Oil and Gas Complex], vol. 1, pp. 62-66 (in Russian).

Bocharnikov V. (2018a) Geokod tsivilizatsii i «glubinnaya ekologiya» v epokhu globalizatsii [Geocode of the Civilization and "Deep Ecology" in the Globalization]. Pskovskii regionologicheskii zhurnal [Pskov Regional Studies], no 1(33), pp. 1-15. DOI: $10.3109 / 08830185.2014 .902452$ (in Russian).

Bocharnikov V. (2018b) Kontsept Ojkumeny $i$ vizualizatsiya poznaniya v sovremennom diskurse geografii [The Concept of the Populated Universe and the Visualization of Knowledge in the Discourse of Geography]. Gumanitarnyj vektor [Humanitarian Vector], vol. 13, no 2, pp. 132-141. DOI: 10.21209/1996-7853-2018-13-2-132-141 (in Russian).

Bouoiyour J., Selmi R. (2020) Coronavirus Spreads and Bitcoin's 2020 Rally: Is There a Link? (HAL Working Paper hal-02493309). DOI: 10.13140/RG.2.2.16003.86561. Available at: https://hal.archives-ouvertes.fr/hal-02493309, accessed 13.04.2020.

Brahmbhatt M., Dutta A. (2008) Economic Effects during Outbreaks of Infectious Disease, Washington, D.C.: WorldBank.Availableat:http://siteresources.worldbank.org/DEC/Resources/84797-1154354760266/2807421-1194369100631/ 4361465-1202937271771/Economic-Effects-during-Outbreaks.pdf, accessed 11.04.2020. 
Cao Y., Carver S., Yang R. (2019) Mapping Wilderness in China: Comparing and Integrating Boolean and WLC approaches. Landscape and Urban Planning, vol. 192, art. 103636. Available at: https://doi.org/10.1016/j.landurbplan.2019.103636, accessed 02.03.2020.

Chen X. (1990) Input-Occupancy-Output Analysis and Its Application in China. Dynamics and Conflict in Regional Structural Change: Essays in Honour of Walter Isard, vol. 2 (eds. M. Chatterji, R.E. Kuenne), Heidelberg, New York, Dordrecht, London: Springer, pp.267-278. DOI: 10.1007/978-1-349-10636-3.

Chou S.K., Costanza R., Earis P., Hubacek K., Li L.B., Lu Y., Span R., Wang H., Wu J., Wu Y., Yan J.J. (2018) Priority areas at the frontiers of ecology and energy. Ecosystem Health and Sustainability, vol. 4, no 10, pp. 243-246. DOI: $10.1080 / 20964129.2018 .1538665$.

Cleveland C.J. (1999) Biophysical economics: From physiocracy to ecological economics and industrial ecology. Bioeconomics and Sustainability: Essays in Honor of Nicholas Gerogescu-Roegen (eds. J. Gowdy, K. Mayumi), Cheltenham: Edward Elgar, pp. $125-154$.

Costanza R., Kubiszewski I., Giovannini E., Lovins L.H., Mcglade J., Pickett K.E., Ragnarsdottir K.V., Roberts D.C., De Vogli R., Wilkinson R. (2015) Time to leave GDP behind. Nature, vol. 505, no 3, pp. 283-285.

CIC Advisor (2020) Investment Climate in Russia - Current State and Outlook for 2020-2024. Available at: http://www.ocn. com.cn/2012/1089eluositouzihuanjing.shtml, accessed 23.04.2020 (in Chinese).

CRS (2020) COVID-19: US-China Economic Considerations, Washington, D.C.: Congressional Research Service. Available at: https://crsreports.congress.gov/product/pdf/IF/IF11434, accessed 13.04.2020.

Daly H.E. (2007) Ecological Economics and Sustainable Development, Selected Essays of Herman Daly, Cheltenham (UK), Northampton, MA: Edward Elgar.

Daly H.E., Farley J. (2004) Ecological economics: Principles and applications. Ecological Economics, vol. 55, no 1, pp. 538-541. DOI: $10.1017 / \mathrm{CBO} 9781107415324.004$.

Duan H., Wang S., Yang C. (2020) Coronavirus: Limit short-term economic damage. Nature, vol. 578, p. 515. Available at: https://www.nature.com/articles/d41586-020-00522-6, accessed 07.03.2020.

Hall C.A.S., Lambert J.G., Balogh S.B. (2014) EROI of different fuels and the implications for society. Energy Policy, vol. 64, pp. 141-152. DOI: 10.1016/j.enpol.2013.05.049.

Interfax (2010) Metodika otsenki ekologicheskoi i energeticheskoi effektivnosti ekonomiki Rossii [Methodology for the estimation of ecological and energy efficiency of Russian economy], Moscow: Interfax. Available at: https://interfax-era. ru/metodologiya/kniga, accessed 23.04.2020 (in Russian).

Lambert J.G., Hall C.A.S., Balogh S., Gupta A., Arnold M. (2014) Energy, EROI and quality of life. Energy Policy, vol. 64, pp. 153-167. DOI: 10.1016/j.enpol.2013.07.001.

Lanjian C., Wei Z. (2016) China energy resources oriented OBOR: Research on OBOR growth strategy of China. Basic Research Journal of Social and Political Science, vol. 4, no 1, pp. 1-14. Available at: https://www.basicresearchjournals.org/social\%20 political\%20science/pdf/Lanjian\%20and\%20Wei.pdf, accessed 12.03.2020.

Leontief W. (2008) Input-output analysis, Heidelberg, New York, Dordrecht, London: Springer.

Lippi G., Plebani M. (2020) The novel coronavirus (2019-nCoV) outbreak: Think the unthinkable and be prepared to face the challenge. Diagnosis, vol. 7, no 1, pp. 8-10. DOI: 10.1515/dx-2020-0015. Available at: https://www.degruyter.com/view/ journals/dx/ahead-of-print/article-10.1515-dx-2020-0015/article-10.1515-dx-2020-0015.xml, accessed 23.02.2020.

Liu W., Dunford M., Gao B. (2018) A discursive construction of the Belt and Road Initiative: From neo-liberal to inclusive globalization. Journal of Geographical Sciences, vol. 28, no 9, pp. 1199-1214. DOI: 10.1007/s11442-018-1520-y.

Ma L., Liu P., Fu F., Li Z., Ni W. (2011) Integrated energy strategy for the sustainable development of China. Energy, vol. 36, no 2, pp. 1143-1154. DOI: 10.1016/j.energy.2010.11.035.

Malle S. (2017) Russia and China in the 21st century. Moving towards cooperative behaviour. Journal of Eurasian Studies, vol. 8, no 2, pp. 136-150. DOI: 10.1016/j.euras.2017.02.003.

McCloskey B., Heymann D.L. (2020) SARS to novel coronavirus - Old lessons and new lessons. Epidemiology and Infection, vol. 148, art. e22. DOI: 10.1017/S0950268820000254. Available at: https://www.ncbi.nlm.nih.gov/pmc/articles/ PMC7026896/, accessed 16.04.2020.

NBS (2020) China Statistical Yearbook, 2019, Beijing: National Bureas of Statistics. Available at: http://www.stats.gov.cn/tjsj/ ndsj/2019/indexch.htm, accessed 23.04.2020 (in Chinese).

Oliveira C., Antunes C.H. (2011) A multi-objective multi-sectoral economy-energy-environment model: Application to Portugal. Energy, vol. 36, no 5, pp. 2856-2866. DOI: 10.1016/j.energy.2011.02.028.

Pan W., Wu P., Hu C., Tu H. (2019) Assessing the green economy in China: An improved framework. Journal of Cleaner Production, vol. 209, pp. 680-691. DOI: 10.1016/j.jclepro.2018.10.267. 
Redding D.W., Atkinson P.M., Cunningham A.A., Lo Iacono G., Moses L.M., James L., Wood N., Jones K.E. (2019) Impacts of environmental and socio-economic factors on emergence and epidemic potential of Ebola in Africa. Nature Communications, vol. 10, no 1, art. 4531. DOI: 10.1038/s41467-019-12499-6. Available at https://www.nature.com/articles/ s41467-019-12499-6, accessed 10.04.2020.

Sarker M.O.F. (2014) Python Network Programming, Birmingham (UK): Packt Publishing. Available at: http://it-ebooks.info/ book/3515, accessed 14.01.2020.

Scellato S. (2013) NetworkX : Network Analysis with Python Today's Outline. Available at: https://www.cl.cam.ac.uk/ cm542/ teaching/2011/stna-pdfs/stna-lecture11.pdf, accessed 17.03.2020.

Siu A. (2004) The Economic Impact of SARS: The Case of Hong Kong. At the Epicentre: Hong Kong and the SARS Outbreak 2004 (ed. C. Loh), Hong Kong: Hong Kong University Press, pp. 179-193.

Smith K.M., Machalaba C.C., Seifman R., Feferholtz Y., Karesh W.B. (2019) Infectious disease and economics: The case for considering multi-sectoral impacts. One Health, art. 100080. DOI: 10.1016/j.onehlt.2018.100080. Available at: https:// www.ncbi.nlm.nih.gov/pmc/articles/PMC6330263/, accessed 04.03.2020.

Steblyanskaya A., Wang Z. (2019) Are Sustainable Growth Indicators in Gas Market Companies Comparable ? The Evidence from China and Russia. Journal of Corporate Finance Research, vol. 13, no 1, pp. 76-92. Available at: https://doi. org/10.17323/j.jcfr.2073-0438.13.1.2019.76-92, accessed 02.03.2020.

Svetlicinii A. (2018) China's Belt and Road Initiative and the Eurasian Economic Union: Integrating the Integrations. Public Administration Issues, no 5, pp. 7-20. DOI: 10.17323/1999-5431-2018-0-5-7-20.

Suarez F., Nuno, P., Granda G., Garcia F.D. (2015), Computer networks performance modeling and simulation. Modeling and Simulation of Computer Networks and Systems - Methodologies and Applications (eds. M.S. Obaidat, P. Nicopolitidis, F. Zarai), Amsterdam: Elsevier - Morgan Kaufmann, pp.187-223. DOI: 10.1016/B978-0-12-800887-4.00007-9.

Ward J.D., Sutton P.C., Werner A.D., Costanza R., Mohr S.H., Simmons C.T. (2016) Is Decoupling GDP Growth from Environmental Impact Possible? PLoS One, vol. 11, no 10, art. e0164733. Available at: https://doi.org/10.1371/journal. pone.0164733, accessed 09.02.2020.

Weidong L. (2019) Joint Construction of Green Silk Roads: Social, Economic and Environmental Context, Beijing: The Commercial Press.

Wen J., Aston J., Liu X., Ying T. (2020) Effects of misleading media coverage on public health crisis: A case of the 2019 novel coronavirus outbreak in China. Anatolia, vol. 31. DOI: 10.1080/13032917.2020.1730621. Available at: https://www. tandfonline.com/doi/full/10.1080/13032917.2020.1730621, accessed 07.04.2020.

WHO (2020) Preparing for large-scale community transmission of 2019-nCoV. Guidance for countries and areas in the WHO Western Pacific Region, Geneva: World Health Organization.

Wong L., Wu Q., Chen X., Chen Z., Alias H., Shen M., Hu J., Duan S., Zhang J., Han L. (2020) The role of institutional trust in preventive and treatment-seeking behaviours during the 2019 novel coronavirus (2019-nCoV) outbreak among residents in Hubei, China. Available at: https://www.medrxiv.org/content/10.1101/2020.02.15.20023333v1, accessed 03.04.2020.

WTO (2020) Trade set to plunge as COVID-19 pandemic upends global economy (press release), Geneva: World Trade Organization. Available at: https://www.wto.org/english/news_e/pres20_e/pr855_e.htm, accessed 13.04.2020.

Yan J., Feng L., Denisov A., Steblyanskaya A., Oosterom J.P. (2020) Correction: Complexity theory for the modern Chinese economy from an information entropy perspective: Modeling of economic efficiency and growth potential. PloS One, vol. 15, no 3, art. e0230165. DOI: 10.1371/journal.pone.0230165. 